\title{
eemeraldinsight
}

\section{Journal of Knowledge Management}

How ability, motivation and opportunity influence travel agents performance: the moderating role of

absorptive capacity

Ahmed Mohamed Elbaz, Gomaa Mohamed Agag, Nasser Alhamar Alkathiri,

\section{Article information:}

To cite this document:

Ahmed Mohamed Elbaz, Gomaa Mohamed Agag, Nasser Alhamar Alkathiri, (2018) "How ability, motivation and opportunity influence travel agents performance: the moderating role of absorptive capacity", Journal of Knowledge Management, Vol. 22 Issue: 1, pp.119-141, https://doi.org/10.1108/JKM-07-2017-0308

Permanent link to this document:

https://doi.org/10.1108/JKM-07-2017-0308

Downloaded on: 30 March 2018, At: 13:17 (PT)

References: this document contains references to 103 other documents.

To copy this document: permissions@emeraldinsight.com

The fulltext of this document has been downloaded 139 times since 2018*

\section{Users who downloaded this article also downloaded:}

(2018),"Exploring the antecedents and consequences of the transactive memory system: an empirical analysis", Journal of Knowledge Management, Vol. 22 Iss 1 pp. 92-118 <a href="https://doi.org/10.1108/JKM-03-2017-0092">https:// doi.org/10.1108/JKM-03-2017-0092</a>

(2018),"Factors affecting Web 2.0 adoption: exploring the knowledge sharing and knowledge seeking aspects in health care professionals", Journal of Knowledge Management, Vol. 22 Iss 1 pp. 21 -43 <a href="https://doi.org/10.1108/ JKM-08-2016-0320">https://doi.org/10.1108/JKM-08-2016-0320</a>

Access to this document was granted through an Emerald subscription provided by

\section{For Authors}

If you would like to write for this, or any other Emerald publication, then please use our Emerald for Authors service information about how to choose which publication to write for and submission guidelines are available for all. Please visit www. emeraldinsight. com/ authors for more information.

\section{About Emerald www.emeraldinsight.com}

Emerald is a global publisher linking research and practice to the benefit of society. The company manages a portfolio of more than 290 journals and over 2,350 books and book series volumes, as well as providing an extensive range of online products and additional customer resources and services.

Emerald is both COUNTER 4 and TRANSFER compliant. The organization is a partner of the Committee on Publication Ethics (COPE) and also works with Portico and the LOCKSS initiative for digital archive preservation.

*Related content and download information correct at time of download. 


\section{How ability, motivation and opportunity influence travel agents performance: the moderating role of absorptive capacity}

Ahmed Mohamed Elbaz, Gomaa Mohamed Agag and Nasser Alhamar Alkathiri

\begin{abstract}
Purpose - This study aims to examine the influence of the three dimensions of travel agents' manager competencies - ability, motivation and opportunity seeking - on knowledge transfer and travel agents' performance. In addition, the study investigates how employee's absorptive capacity moderates the effects of managers' competencies on knowledge received by the employees and moderates the effects of knowledge received by the employees on travel agents' performance.

Design/methodology/approach - A positivist research philosophy was adopted with a quantitative approach, in which quantitative data were gathered based on questionnaires to tackle different stages of the study. To test the hypotheses, a self-administrated face-to-face survey of about 42 questions, launched on November 7, 2016, was used to compile response from top and medium management Category A travel agents operating in Egypt.

Findings - Based on a sample of 577 travel agents' frontline employees, the results showed that the three dimensions of travel agents' competencies have a positive effect on knowledge received by the employee. Findings further indicated that knowledge received by employee mediates the link between these three competencies and travel agents' performance. The link between the competencies and knowledge received by the employee was found to be positively moderated by employee absorptive capacity. Moreover, these findings suggested that the relationship between knowledge received and travel agents' performance is stronger when employees' absorptive capacity is greater.
\end{abstract}

Research limitations/implications - This study is bound by certain limitations that also provide fertile grounds for further research. First, the study examined how an employee's absorptive capacity moderates the effects of managers' competencies on knowledge received by the employees and moderates the effects of knowledge received by the employees on travel agents' performance. However, innovation as a dependent variable can be investigated. Second, one limitation is that the study is restricted to Category A travel agents only in Greater Cairo. Third, examining the antecedents of ability, motivation and opportunity seeking to transfer knowledge is also important.

Practical implications - It is important for travel agents, owners, managers and employees to acknowledge absorptive capacity as a critical component for organizations to sustain, grow and compete. Travel agents can also take steps to develop their employees' absorptive capacity. Doing so would further enhance the success of knowledge, employees and travel agents' performance. Also, travel agents' top management has to ensure their employees' absorbing knowledge, identifying and recognizing external knowledge, processing and understanding it, combining it with existing knowledge and applying the new knowledge to commercial ends. Hence, the development of absorptive capacity contributes to a travel agent's achievement of competitive advantage.

Originality/value - This study contributes to the literature by expanding the extant literature on knowledge transfer and absorptive capacity by investigating the influence of travel agents' manager competencies - ability, motivation and opportunity seeking - for knowledge transfer in the Egyptian context. In addition, it investigates the direct effects of the three dimensions of travel agents' manager competencies - ability, motivation and opportunity seeking - for knowledge transfer. Finally, the paper investigates how employee's absorptive capacity moderates the effects of managers' competencies on
Ahmed Mohamed Elbaz is

Assistant Professor at the

Business Administration

Department, College of

Applied Sciences, Salalah,

Sultanate of Oman, and

Tourism Studies

Department, Faculty of

Tourism and Hotels,

University of Sadat City, Menoufia, Egypt.

Gomaa Mohamed Agag

is Senior Lecturer of

Marketing at Nottingham

Business School,

Nottingham Trent

University, Nottingham,

UK, and University of

Sadat City, Sadat City,

Menofia, Egypt.

Nasser Alhamar Alkathiri

is Acting Head of

Business Administration

Department at the

Department of Business

Administration, Salalah

College of Applied

Sciences, Salalah, Oman.

Received 28 July 2017

Revised 28 July 2017

Accepted 8 October 2017 
knowledge received by the employees and moderates the effects of knowledge received by the employees on travel agents' performance

Keywords Egypt, Knowledge transfer, Absorptive capacity, Ability-motivation-opportunity framework, Travel agents

Paper type Research paper

\section{Introduction}

Human capital is one of the main assets in organizations, which is capable of survival and success if managed effectively. Hence, managers must pay attention to the human investment (Dobre, 2013; McGehee et al., 2010). Enhancing employees' performance and improving the competitive advantages of an organization are mainly based on the ability to transfer knowledge from the source to the recipients (Jimenéz-Jimenéz et al., 2014). Thus, transfer knowledge from the source to recipient is vital to the success of organization performance (Lin et al., 2016; Wood et al., 2016).

A globalized world is characterized by fast knowledge transfer across large geographic areas via the internet. Therefore, the consequence of this globalization is the emergence of knowledge-based economies where significance is placed on effective management of human capital to ensure that workers continue to create the right value for the economy (Omotayo, 2015). Today, organizations no longer compete solely on the basis of financial capital and strength. Knowledge is the new competitive advantage in business, knowledge which is considered as a core competence for organizations (Anantatmula and Stankosky, 2008). Knowledge is often defined as a "justified personal belief" (Nonaka, 1994, p. 15; McCall, Arnold and Sutton, 2008; Frechtling, 2004) and value creation (Massa and Testa, 2009). Knowledge is a justified personal belief that increases an individual's capacity to take effective action (Wei and Xie, 2008). There are many taxonomies that specify various kinds of knowledge (Zack, 1999). Smith (2001) claimed that the most fundamental distinction is between "tacit" and "explicit" knowledge. Tacit knowledge inhabits the minds of people and is (depending on one's interpretation of Polanyi's (1966) definition) either impossible or difficult to articulate. Explicit knowledge exists in the form of words, sentences, documents, organized data, computer programs and in other explicit forms (Meihami and Meihami, 2014). If one accepts the useful "difficult-to-articulate" concept of tacit knowledge, a fundamental problem of knowledge management (KM) is to explicate tacit knowledge and then to make it available for use by others (Zack, 1999).

The term KM can be defined by Hislop (2013) as a systematic and organized approach to improve the ability of the organization to mobilize knowledge to enhance decision-making, take actions and deliver results in support of the underlying business strategy. Another commonly used model defines the following stages in the knowledge process: identification, acquisition, development, distribution, use and retention (Hussain et al., 2004). McCall et al. (2008) stated that KM can be defined as the organizational "efforts designed to (A) capture knowledge; (B) convert personal knowledge to group-available knowledge; (C) connect people to people, people to knowledge, knowledge to people, and knowledge to knowledge; and (D) measure that knowledge to facilitate management of resources and help understand its evolution".

The management of knowledge has generated a considerable interest in business and management circles due to its capability to deliver to organizations, strategic results relating to profitability, competitiveness and capacity enhancement (Jeon et al., 2011). Therefore, successful organizations nowadays understand why they must manage knowledge, develop plans as to how to accomplish this objective and devote time and energy to these efforts. This is because $\mathrm{KM}$ has been described as a key driver of organizational performance (Bosua and Venkitachalam, 2013) and one of the most important resources for the survival and prosperity of organizations (Kamhawi, 2012). KM should be used to solve business problems. Therefore, the key to effectively managing

PAGE 120 | JOURNAL OF KNOWLEDGE MANAGEMENT | VOL. 22 NO. 12018 
knowledge is to identify importance of knowledge for the organization and to create processes to utilize that knowledge (Anantatmula and Stankosky, 2008).

Chang et al. (2012) contended that the supporters of the KM theory have identified ability, motivation and opportunity as important for explaining the creation and transfer of knowledge. Hence, the successful performance of any task in an organization, which is based on the ability, motivation and opportunity to transfer knowledge to a recipient (e.g. employees, subsidiaries companies), depends on knowledge source (e.g. managers, parent companies, expatriates) ability, motivation and opportunity to perform the transfer. Furthermore, Szulanski (1996) and Yahiaoui et al. (2016) argued that theorists have also identified recipient absorptive capacity as a critical factor in the successful transfer of knowledge. This signifies that once knowledge received by subsidiaries, companies or employees, must be better and successfully absorbed and utilized to contribute more to recipients and the overall performance of the organization.

The present study suggests that managers' competencies in knowledge transfer enhance knowledge received by the employee, which in turn improves employee performance. Furthermore, employee absorptive capacity moderates the first link (i.e. the relationship between managers' competencies in knowledge transfer and knowledge received by the employee) and the second link (i.e. the relationship between knowledge received by the employee and employee's performance) in the mediation relationship, contributing to the current literature because, to the best of knowledge, this has not been done in any other study. Therefore, the current study aims to contribute the following to the literature of tourism and hospitality:

- This study contributes to the literature by expanding the extant literature on knowledge transfer and absorptive capacity by investigating the influence of travel agents' manager competencies - ability, motivation and opportunity seeking - for knowledge transfer in the Egyptian context.

- Despite the theoretical aspect attributed to ability, motivation and opportunity framework and absorptive capacity, comparatively little research focuses on its role within manager-employee relationships in travel agents in developing countries.

- This study also investigates the direct effect of the three dimensions of travel agents' manager competencies - ability, motivation and opportunity seeking - for knowledge transfer.

- This study investigates how employee's absorptive capacity moderates the effects of managers' competencies on knowledge received by the employees and moderates the effects of knowledge received by the employees on travel agents' performance

Our study is organized as follows: The next section outlines the Egyptian tourism context and highlights the need of such research in a key sector within the country. Thereafter, the theoretical framework and hypotheses are developed, followed by an overview of the research methods and findings. Finally, the results are discussed and conclusions are drawn.

\section{Tourism sector in Egypt}

Considered as the key engine for Egypt's economic growth, the Egyptian tourism sector can be seen as an important source of foreign exchange and a significant generator of directly related and indirectly related jobs (Richter and Steiner, 2008). Tourism in Egypt is associated with approximately 70 feeder services and complementary industries, representing about 40 per cent of Egypt's non-commodity exports (Hilmi et al., 2012). The tourism boom has had a great effect on Egypt's economic development. In most cases, Egypt can be seen as a perfect example of the positive economic outcomes of tourism, which seem to outweigh its negative effects (Steiner, 2006). Tourism is considered one of

VOL. 22 NO. 12018 JOURNAL OF KNOWLEDGE MANAGEMENT $\mid$ PAGE 121 
the most important pillars of Egypt's economy. For example, in 2013, the tourism sector employed about 12.6 per cent of Egypt's workforce, serving approximately 14.7 million tourists and providing incomes of nearly \$19bn (Agag and El-Masry, 2017). Egypt accrued $\$ 6.1 \mathrm{bn}$ in tourism revenue in 2015 , as the total number of tourists dropped by 6 per cent to 9.3 million and the total number of tourist nights declined by 14 per cent (Egyptian Ministry of Tourism, 2015).

Perceived as a crucial stakeholder in the tourism sector, travel agents are essential to the development and success of this sector. They are increasingly considered as the most powerful and influential player within the sector through their role as "sales agents" in the distribution of packaged holidays and destinations (Baloglu and Mangaloglu, 2001).

\section{Theoretical background and hypotheses}

To date, ability, motivation and opportunity framework has been theoretically developed and empirically tested as a robust theoretical lens that provides insights into knowledge sharing (Turner and Pennington, 2015). Transfer knowledge requires the willingness of a group or an individual to work with others and share knowledge to their mutual benefit. Therefore, it is impossible to transfer knowledge without sharing. This indicates that managers, employees and work group should have a high level of co-operation to ensure transferring knowledge successfully (Syed-Ikhsan and Rowland, 2004). Siemsen et al. (2008) argued that ability, motivation and opportunity have been documented as the building blocks of any successful action. Lawson and Potter (2012) contended that applying the ability, motivation and opportunity framework may help overcome an organization's internal stickiness in knowledge transfer.

Ability refers to the talent, knowledge, skills, proficiency and experience required to achieve a task. Motivation refers to the willingness (or the degree to which an individual is motivated) to perform it. Chang et al. (2012, p. 929) defined opportunity seeking as "the search and utilization of resources and opportunities through social relationships to solve difficulties in transferring knowledge". According to Nahapiet and Ghoshal (1998), the ability of organizations to generate new knowledge and apply its results stems from the collective ability of organizational members to generate, learn, understand, share and utilize knowledge. According to Tho and Trang (2015), motivation helps individuals establish and improve the quality of cognitive engagement, leading to success. Ability, motivation and opportunity have been identified in relation to specific tasks. For example, motivation to learn refers to "a desire on the part of trainees to learn the content of the training program" (Colquitt and Simmering, 1998, p. 654). The research conceptual framework and hypotheses are shown in Figure 1.

\subsection{The ability, motivation and opportunity and knowledge received by employees}

Studies on knowledge processes in organizations realize the role of ability, motivation and opportunities as an important framework for explaining the creation and transfer of knowledge (Kelloway and Barling, 2000). Based on the theoretical development of Chang et al. (2012), the carrier of knowledge competencies in knowledge transfer increases knowledge received by the recipients to which the carrier of knowledge have been assigned, which in turn enhances recipients' performance. For example, Argote et al. (2003) argued that successful people's performance is based on people's ability, motivation and opportunities to perform; successful KM is also based on ability, motivation and opportunity. The study findings of Turner and Pennington (2015) revealed that motivation and opportunity are positively associated with knowledge sharing; however, ability is negatively associated with knowledge sharing. Minbaeva et al. (2003) suggested that a higher rating of knowledge utilization will be achieved if the recipients of knowledge have the ability and motivation to absorb new external knowledge. In addition, Wang and Noe (2010) indicated that if the ability, motivation and opportunity seeking to transfer 
Figure 1 Theoretical framework and hypotheses

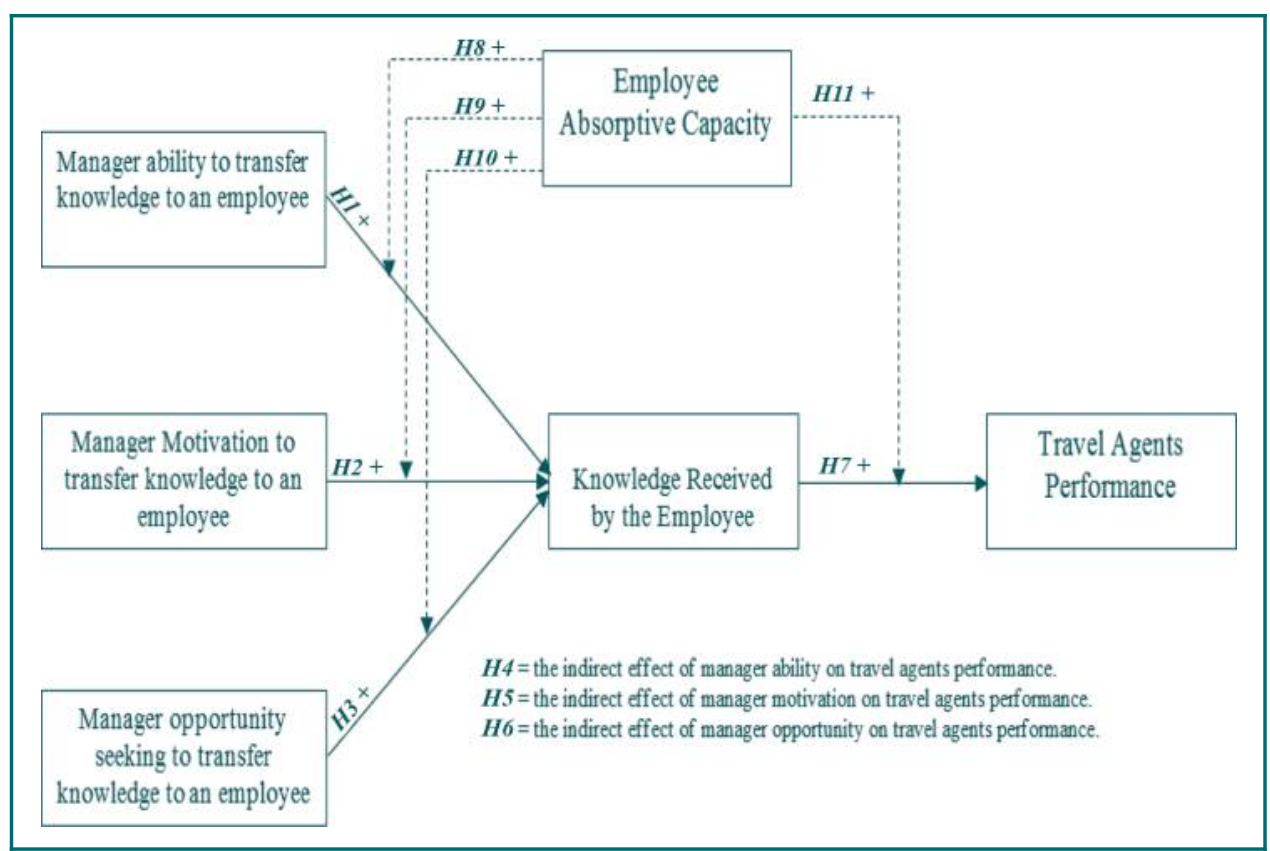

knowledge of carriers are strong, the receivers will get more advanced knowledge from the carriers, which leads to the result that employees can transform the knowledge into productive forces and improve the performance of an organization. Thus, the researcher shares these arguments toward ability, motivation and opportunity and knowledge sharing in travel agents and proposes the following hypotheses:

H1. Managers ability to transfer knowledge to an employee positively influences knowledge received by the employee in travel agents.

H2. Managers motivation to transfer knowledge to an employee positively influences knowledge received by the employee in travel agents.

H3. Managers opportunity seeking to transfer knowledge to an employee positively influences knowledge received by the employee in travel agents.

\subsection{Mediating role of knowledge received by employees}

Knowledge not only can be transferred from person-to-person but also includes person to group or a team, group or team to person or team or group to team or group (Syed-Ikhsan and Rowland, 2004; Sanchez-Vidal et al., 2016). Therefore, the process of knowledge transfer involves both transmission (by managers, in this study) and receipt (by employees) of knowledge (Chang et al., 2012). In other words, Davenport and Prusak (1998, p. 101) contented that knowledge transfer includes two tasks which are "transmission (sending or presenting knowledge to a potential recipient) and absorption by that person or group". In addition, Seidler-de Alwis and Hartmann (2008) and Fei et al. (2009) found that the amount of knowledge received by the recipients from manager competencies in transferring knowledge within an organization plays a vital role in knowledge transfer process.

Through socialization, education and learning, knowledge transfers happen (Roberts, 2000). In this sense, education and training can be the basis for strengthening constant knowledge transfer to help get employees engaged in the KM process. Thus, managerial attention must be dedicated to developing the learning capacities of the organization (Fei et al., 2009). Thus, managers, as the source and carriers of knowledge, must have the ability to communicate good ideas about their business (Turner and Pennington, 2015) and

VOL. 22 NO. 12018 JOURNAL OF KNOWLEDGE MANAGEMENT $\mid$ PAGE 123 
possess superior managerial competencies (knowledge, skills and experience) to solve difficulties in the knowledge transfer process (Chang et al., 2012). Hence, when the source of knowledge has the ability to solve difficulties in the transfer process, the knowledge received by the recipient from carriers of the knowledge should increase (Peng, 2011). Moreover, source managers' knowledge transfer capacity is the ability to articulate uses of their own knowledge, assess the needs and capabilities of the potential recipient and transmit knowledge so that it can be put to use within the recipient organization (Martin and Salomon, 2003). However, Schreiber et al. (2011) argued that the crucial element in knowledge transfer is not the carrier of the original knowledge but the receiver's perception of the effectiveness and applicability of this transmitted knowledge in its operations. Thus, Wang and Wang (2012) confirmed that the process of knowledge transfer is based not only on the cognitive characteristics of the user that is the focus of the interpretation but also on the method by which it is presented to the user and represented by the codification used to distinguish that specific knowledge.

Abdul-Jalal et al. (2013) argued that managers have the ability to increase the level of knowledge sharing success by ensuring that the design of human resources management practices are customized to support the maximizing of employees' knowledge sharing capabilities. Chang et al. (2012) argued that ability, motivation, and opportunity seeking to solve difficulties in transferring knowledge increase the knowledge received by a recipient. Junni et al. (2012) argue that for the knowledge transfer to be effective, the sender should be motivated to explain and frame the knowledge and to support its interpretation for the recipient. In addition, the recipient should have the ambition to recognize and receive the knowledge and utilize it for his/her own purpose and context. Therefore, Junni et al. (2012, p. 6) define knowledge transfer as "the receiver's use of the sender's knowledge". Based on the aforementioned arguments, it can be argued that the ability, motivation and opportunity of manager competencies will maximize the knowledge received by the employees, which in turn will enhance employee performance (Chang et al., 2012). The study's conceptual framework proposes that knowledge received by an employee from managers mediates the relationship between manager competencies in knowledge transfer and travel agent performance. Based on this discussion, the following hypotheses are proposed:

H4. Managers' ability to transfer knowledge to an employee has an indirect effect on travel agent performance.

H5. Managers' motivation to transfer knowledge to an employee has an indirect effect on travel agent performance.

H6. Managers' opportunity seeking to transfer knowledge to an employee has an indirect effect on travel agent performance.

\subsection{Knowledge transfer and travel agents's performance}

Generally, the term knowledge transfer refers to an event through which one organization learns from the experience of another (Darr et al., 1995). Knowledge transfer can be measured by its influence on changes in organizations performance (Argote and Ingram, 2000). Syed-Ikhsan and Rowland (2004) and Yusof and Bakar (2012) demonstrated that knowledge transferring from one to another within an organization contributes to its performance. Studies by Lesser and Storck (2001) and Johnson (2007) found communities of practice to be an effective way for organizations to transfer tacit knowledge among workers and improve organizational performance. Moreover, for organization to maximize and achieve the competitive advantage and consistently high performance arising from knowledge, knowledge must be effectively transferred within organizations (Murray and Peyrefitte, 2007).

Hussain et al. (2004) argued that achieving high project performance depends on the level of effort of knowledge transfer and the body of knowledge of the project managers.

PAGE 124 | JOURNAL OF KNOWLEDGE MANAGEMENT | VOL. 22 NO. 12018 
Although the benefits of transfer knowledge have been documented in many settings of manufacturing and services (Paulin and Suneson, 2012), the effectiveness of knowledge transfer varies considerably among organizations (Ajmal and Koskinen, 2008). To sum up, in this study, if the travel agent managers are willing to transfer knowledge, they can overcome all the difficulties to transfer knowledge to employees, which will actively enhance the travel agent performance. Based on these arguments, the author posited the following hypothesis:

H7. Knowledge received by employees positively influences travel agents' performance.

\subsection{Moderating role of employees' absorptive capacity}

This study investigates how an employee's absorptive capacity moderates the effects of managers' competencies on knowledge received by the employees and moderates the effects of knowledge received by the employees on travel agents' performance. According to Cohen and Levinthal (1990), corporate performance is linked to the learning capabilities of an organization or its "absorptive capacity". As Adler (1965), Kamal and Flanagan (2014) and Kocoglu et al. (2015) explained, the concept of absorptive capacity originates from macroeconomics where it refers to the ability of an economy to effectively utilize its capital resources. Cohen and Levinthal (1990, p. 128) and Minbaeva et al. (2003) defined absorptive capacity as "the ability of a firm to recognize the value of new, external information, assimilate it, and apply it to commercial ends". Zahra and George (2002) gave a comprehensive definition of absorptive capacity in which they described it as a set of organizational procedures and processes by which organizations acquire, assimilate, transform and exploit knowledge to create a dynamic organizational capability. Based on these definitions, four components of absorptive capacity have been identified:

1. identifying and recognizing external knowledge;

2. processing and understanding it;

3. combining it with existing knowledge; and

4. applying the new knowledge to commercial ends(Chang et al., 2012; Kocoglu et al., 2015).

Absorptive capacity has also been acknowledged as a critical component for organizations to sustain, grow and compete in their market. As Minbaeva et al. (2003) mentioned the concept of absorptive capacity has been used as a key concept for understanding the conditions for effective learning. There is no doubt that absorptive capacity has been one of the most repeatedly mentioned and investigated terms in organization management during the past two decades (Volberda et al., 2009). It is, therefore, a fascinating concept to understand how companies develop the ability to capture learning components within and outside themselves, then retain such knowledge and finally make use of it to improve their decisions and their organizational performance (Kocoglu et al., 2015). The absorptive capacity of an organization is not, however, simply the sum of the absorptive capacities of its employees, and it is, therefore, useful to consider what aspects of absorptive capacity are distinctly organizational (Cohen and Levinthal, 1990). Absorptive capacity results from a prolonged process of investment and knowledge accumulation Tsai (2001). The absorptive capacity of an organizational unit for learning depends on its endowment of relevant technology-based capabilities (Mowery et al., 1996).

Therefore, to have successful exploitation of newly acquired knowledge, there must be a sharing of knowledge among members of the firm. Social integration mechanisms can facilitate the process and reduce the gap between potential absorptive capacities and realized absorptive capacity (Zahra and George, 2002). The successful development of absorptive capacity will contribute to a firm's achievement of competitive advantage

VOL. 22 NO. 12018 JOURNAL OF KNOWLEDGE MANAGEMENT | PAGE 125 
(Kamal and Flanagan, 2014). According to Szulanski (1996), the lack of absorptive capacity is viewed as a deficiency in the knowledge transfer process. In addition, Ismail (2015) indicated that it is possible that employees will perceive the knowledge from the carriers to be foreign and less valuable in their local context and, therefore, will not actively learn from carriers, leading to less knowledge received or acquired by the employees. Thus, Chang et al. (2012, p. 931) suggested that "lower or greater recipients' absorptive capacity would weaken or strengthen the relationship between the carrier of knowledge competencies in knowledge transfer and knowledge received by the recipients at which they are working". Moreover, Schreiber et al. (2011) argued that poor absorptive capacity leads to the isolation of the recipient of knowledge and, thus, lower contribution in knowledge transfer. Hence, the author suggests the following hypotheses:

H8. The relationship between managers' ability to transfer knowledge to employees and knowledge received by the employees is stronger when employees' absorptive capacity is greater.

H9. The relationship between managers' motivation to transfer knowledge to employees and knowledge received by the employees is stronger when employees' absorptive capacity is greater.

H10. The relationship between managers' opportunity seeking to transfer knowledge to employees and knowledge received by the employees is stronger when employees' absorptive capacity is greater.

It is acknowledged that for some organizations, the application of new knowledge and technology may improve their performance, but for others, it may not make any difference, or it may even decrease their productivity (Zahra and George, 2002). Easterby-Smith et al. (2008) demonstrated that absorptive capacity has positively influenced the degree of knowledge transfer. It is also found that absorptive capacity within an organization increases the degree of knowledge transfer (Lawson and Potter, 2012). Szulanski (1996) also confirmed the lack of absorptive capacity, casual ambiguity and relationship difficulties. The research finding of Escribano et al. (2009) suggests that the absorptive capacity is indeed an important source of competitive advantage. In other words, Escribano et al. (2009) concluded that absorptive capacity positively moderates the relationship between external knowledge flows and innovation performance. Tsai (2001, p. 998) stated that "absorptive capacity is also likely to moderate the effect of network position on business unit innovation and performance. For knowledge transfer process to have a strong and lasting influence on organizations performance, Chang et al. (2012) contented that the knowledge received from the carriers of knowledge must become an integral part of the organizations' routines guiding its operations. Thus, in this study, the researcher proposed that absorptive capacity may also moderate the relationship between the knowledge it received by employees and travel agents' performance. Therefore, in the travel agents' context, the following hypothesis has been proposed:

H11. The relationship between knowledge received by employees and travel agents' performance is stronger when employees' absorptive capacity is greater.

\section{Methodology}

\subsection{Sampling and procedures}

A positivist research philosophy was adopted with a quantitative approach, in which quantitative data were gathered based on questionnaires to tackle different stages of the study. To test the hypotheses, a self-administrated face-to-face survey of about 42 questions, launched on November 7, 2016, was used to compile response from top and medium management category A travel agents operating in Egypt. Category A travel agents are those qualified to work globally on tourism activities both inbound and outbound (Abou-Shouk et al., 2016). According to the Egyptian Travel Agents Association (2015), 
there are 1,229 Category A travel agents in Egypt located in Cairo Governorate. Given the high concentration in Greater Cairo and the geographical diffusion of the other governorates throughout Egypt, significant costs, time and difficulties could be involved in delivering and collecting questionnaires outside Greater Cairo. Therefore, as a sampling frame, the focus was on 1,229 Category A travel agents located in Cairo - Egypt. The study survey covers numerous issues, with questions on manager's competencies in knowledge transfer as a whole in travel agents, knowledge received by employees, employee absorptive capacity, travel agents' performance, as well as a final part eliciting feedback on the socio-economic status of numbers, including gender, age, education level, marital status, work experience and occupation.

Based on a systematic random procedure, a representative sample of 728 travel agents was selected, By December 3, 2016, in total, 600 copies were collected from which 577 responses were considered to be valid for further analyses, and all responses with missing values (23) were deemed invalid. This actually meets the suggestion by Bartlett et al. (2001) who determined the sample size for partial least squares (PLS) estimation, ten cases per predictor as a cut-off sample size. In our framework, there are 6 constructs with their 36 indicators and thus needed a minimum of 360 observations. As 577 cases were collected and valid, the current research sample size is a very good and practically acceptable size for the use of PLS. As 577 responses were considered to be valid for further analyses, the current study sample size satisfies the lower sample size threshold for SEM (Westland, 2010).

The aim of the piloting was to refine the questionnaire so that the target respondents will have no difficulties in understanding and answering the questions, and there will be no problem in recording the data (Elbaz and Abou-Shouk, 2016). The 50 returned questionnaires were coded and entered into SPSS (version 22) to test the reliability (internal consistency) and validity of the variable scales. Cronbach's $\alpha$ and corrected item-total correlation were used to measure the reliability and validity of constructs. Item-total correlation is a method commonly used to examine the homogeneity of a scale made up of several items. Reliability analysis was performed on the six constructs and turned out to be highly reliable. Corrected item-total correlations were appropriate, indicating that no item was redundant, and thus no items were deleted. The overall number of indicators involved in the final questionnaire is 36 indicators measuring 6 constructs.

Overall, as can be seen from Table I, the frontline employees involved in the sample were mostly 31-40 years old (53.6 per cent), followed by the $41-50$ years old (27.2 per cent). As for their gender, a significantly higher proportion of males were recorded (approximately 62.3 per cent). This is very common in the Middle-East where a male population usually dominates the work-place (Elbaz and Haddoud, 2017). The vast majority of the travel agents hold at least a Bachelor degree (99.0 per cent). The respondents were mostly married (82.1 per cent), followed by the single, never married (17.3 per cent). Moreover, 25.6 per cent of the participants' experience does not exceed 5 years, and 60 per cent of the sample's experience were mostly 5 to 10 years ( 64.5 per cent). The table also shows that more than third of respondents were reservationist (37.6.7 per cent), followed by sales and marketing employees (17.7 per cent).

\subsection{Measures}

All the six constructs, used in the present, were previously validated and drawn from the administrated questionnaire. Items were assessed on a Likert scale ranging from 1 "strongly disagree" to 5 "strongly agree". Six constructs were measured: ability to transfer knowledge, motivation to transfer knowledge, opportunity seeking to transfer knowledge, knowledge received, absorptive capacity and organization performance. Further details for these measures are provided in the Appendix.

VOL. 22 NO. 12018 JOURNAL OF KNOWLEDGE MANAGEMENT | PAGE 127 
Table I Sample characteristics

Characteristics

Age

$31-40$ years

53.6

41-50 years

27.2

51-60 years

15.4

More than 60 years

Gender

Male

62.3

Female

Education

Bachelor degree

Diploma

Master's degree

Doctorate degree

0.0

Others

Marital status

Single, never married $\quad 17.3$

Married

17.3
82.1

Widowed

0.3

Divorced

Experience

Below 5 years

$5-10$ years

$11-15$ years

25.6

Above 15 years

64.5

Occupation

Customer services

Sales and marketing employees $\quad 17.7$

$\begin{array}{ll}\text { Reservation Ticketing } & 37.6\end{array}$

Religious tourism $\quad 15.1$

Others

4.2.1 Organizational performance. We adopted the five-item scale developed by Conger et al. (2000) and Elbaz and Haddoud (2017) that assessed the extent to which the Egyptian travel agents have improved their ability to compete in the tourism market.

The instruments for the measurement of ability to transfer knowledge (the first three items, $A B|1, A B| 2$ and $A B \mid 3$ ) were based on the works of Chang et al. (2012), whereas the remaining two items (ABI4 and $\mathrm{ABI}$ ) extracted from Turner and Pennington (2015) (Appendix). Motivation to transfer knowledge: the scale originally developed by Chang et al. (2012) and has been modified. Measures for opportunity seeking to transfer knowledge (the first two items, OPP1 and OPP2) were based on the works of Chang et al. (2012), whereas the remaining three items (OPP3, OPP4 and OPP5) were based on Turner and Pennington (2015) (Appendix). The frontline employees in the Egyptian travel agents were asked to assess the extent to which the items accurately described their competencies in knowledge transfer as a whole.

Knowledge received has been measured using a five-item measure by Chang et al. (2012). This measure focuses on the amount of knowledge that the employees received from the managers in the Egyptian travel agents. Similarly, absorptive capacity was analyzed using a four-item scale, which was improved and validated from Ettlie and Pavlou (2006); Lawson and Potter (2012) and Chang et al. (2012). Participant were asked about the extent to which the statements accurately described their employees: identifying and recognizing external knowledge, processing and understanding it, combining it with existing knowledge, and applying the new knowledge to commercial ends. 


\section{Analysis}

An investigation of such a relationship is required and will be pursued through the application of PLS-SEM. Warp PLS 5.0 program was used as it tolerates building a complex conceptual framework of a multi-block analysis, and ultimately, it facilitates the task of estimating all-formative and reflective latent variables (Hair et al., 2016) to validate the measures and test the hypotheses. PLS also minimizes the endogenous variables residual variances (Henseler et al., 2009). Moreover, Lowry and Gaskin (2014) declared that as a SEM, PLS is suitable to examine mediation and moderation hypotheses. Finally, it does not require a normal distribution, as opposed to covariance-based approaches, which requires a normal distribution (Henseler et al., 2016).

\subsection{Measurement model}

Tests of normality were conducted to satisfy the criterion of multivariate normality, namely, skewness, kurtosis and Mahalanobis distance statistics (Bagozzi and Yi, 1988) for all the constructs (Appendix). These indicated no departure from normality. The Cronbach's alpha reliability coefficient was calculated to assess the psychometric properties of the constructs (Nunnally and Bernstein, 1994).

To assess the measurement quality of the constructs used in the study conceptual framework (i.e. the measurement model), the study examined both validity and internal consistency (reliability) for all constructs. Internal consistency of constructs were examined through both composite and Cronbach's $\alpha$ (Table II). Alternatively, constructs validity was assessed through the items loadings (Appendix) and average variance extracted (AVE) for convergent validity (Table II) and the square roots of AVE for discriminant validity and AVE for convergent validity (Table II). Issues of collinearity were also checked, the variance extracted factor (VIF) for all constructs (Table II).

Table II shows that composite reliability and Cronbach's alpha values for each of the latent variables exceeded 0.70, signifying good reliability (MacKenzie et al., 2011). As for convergent validity, all AVEs met the 0.5 minimum value for convergent validity and all items' loadings exceeded the 0.5 threshold (Hair et al., 2016) (Tables II and III). Finally, Table II indicates that all VIFs values were less than five, implying the absence of both multicollinearity and common methods bias (Kock and Lynn, 2012).

In addition, Table III shows that all the retained items had loadings greater than the recommended 0.7 cutoff (Carmines and Zeller, 1979), and that indicators loaded well on

\section{Table II Discriminant validity of the constructs}

\begin{tabular}{|c|c|c|c|c|c|c|}
\hline & & Correlatio & square & of AVEs & & \\
\hline Construct & $A B I$ & MOT & $O P P$ & KNO & $A B S$ & PER \\
\hline $\mathrm{ABI}$ & $(0.816)$ & & & & & \\
\hline MOT & 0.487 & (0.820) & & & & \\
\hline OPP & 0.242 & 0.346 & $(0.720)$ & & & \\
\hline KNO & 0.505 & 0.531 & 0.558 & (0.805) & & \\
\hline ABS & 0.435 & 0.527 & 0.464 & 0.500 & (0.810) & \\
\hline PER & 0.449 & 0.494 & 0.420 & 0.691 & 0.598 & $(0.784)$ \\
\hline Construct & cient & & & & & \\
\hline AVE & 0.610 & 0.715 & 0.647 & 0.549 & 0.608 & 0.620 \\
\hline VIFs & 1.454 & 1.635 & 1.449 & 1.480 & 2.038 & 1.794 \\
\hline CA & 0.895 & 0.912 & 0.917 & 0.899 & 0.898 & 0.891 \\
\hline CR & 0.765 & 0.854 & 0.819 & 0.832 & 0.848 & 0.846 \\
\hline
\end{tabular}

Notes: Italic items are the square root of average variance extracted (AVEs); $A B I=$ ability to transfer knowledge; MOT = motivation to transfer knowledge; OPP = opportunity seeking to transfer knowledge; $\mathrm{KNO}=$ knowledge received by employees; $\mathrm{ABS}=$ employee absorptive capacity; PER = performance; $\mathrm{CA}=$ Cronbach's alpha; $\mathrm{CR}=$ composite reliability 
Table III Loadings and cross-loadings of measurement items

\begin{tabular}{|c|c|c|c|c|c|c|c|}
\hline Items & $A B I$ & MOT & OPP & KNO & $A B S$ & PER & $\mathrm{p}$-value \\
\hline ABI1 & (0.794) & 0.321 & 0.304 & 0.103 & 0.318 & 0.029 & $<0.001$ \\
\hline $\mathrm{ABI} 2$ & (0.836) & 0.409 & 0.602 & 0.411 & 0.347 & 0.384 & $<0.001$ \\
\hline$A B I 3$ & $(0.892)$ & 0.031 & 0.429 & 0.303 & 0.198 & 0.473 & $<0.001$ \\
\hline $\mathrm{ABI} 4$ & $(0.833)$ & 0.311 & 0.133 & 0.092 & 0.429 & 0.372 & $<0.001$ \\
\hline MOT1 & 0.309 & (0.833) & 0.221 & 0.403 & 0.281 & 0.182 & $<0.001$ \\
\hline MOT2 & 0.235 & $(0.890)$ & 0.320 & 0.229 & 0.491 & 0.491 & $<0.001$ \\
\hline MOT3 & 0.264 & $(0.884)$ & 0.119 & 0.323 & 0.118 & 0.218 & $<0.001$ \\
\hline MOT4 & 0.123 & $(0.906)$ & 0.221 & 0.103 & 0.382 & 0.291 & $<0.001$ \\
\hline MOT5 & 0.088 & $(0.832)$ & 0.201 & 0.263 & 0.384 & 0.028 & $<0.001$ \\
\hline OPP1 & 0.223 & 0.421 & $(0.831)$ & 0.231 & 0.172 & 0.481 & $<0.001$ \\
\hline OPP2 & 0.187 & 0.239 & $(0.901)$ & 0.099 & 0.431 & 0.102 & $<0.001$ \\
\hline OPP3 & 0.304 & 0.027 & $(0.901)$ & 0.212 & 0.329 & 0.028 & $<0.001$ \\
\hline OPP4 & 0.045 & 0.333 & (0.893) & 0.521 & 0.129 & 0.002 & $<0.001$ \\
\hline KNO1 & 0.121 & 0.480 & 0.303 & $(0.898)$ & 0.382 & 0.347 & $<0.001$ \\
\hline KNO2 & 0.132 & 0.210 & 0.013 & $(0.803)$ & 0.557 & 0.127 & $<0.001$ \\
\hline KNO3 & 0.231 & 0.494 & 0.211 & $(0.778)$ & 0.349 & 0.487 & $<0.001$ \\
\hline KNO4 & 0.409 & 0.402 & 0.354 & (0.811) & 0.175 & 0.321 & $<0.001$ \\
\hline ABS1 & 0.043 & 0.221 & 0.245 & 0.532 & (0.874) & 0.472 & $<0.001$ \\
\hline ABS2 & 0.328 & 0.290 & 0.328 & 0.039 & (0.904) & 0.227 & $<0.001$ \\
\hline ABS3 & 0.128 & 0.022 & 0.128 & 0.232 & $(0.796)$ & 0.102 & $<0.001$ \\
\hline ABS4 & 0.238 & 0.492 & 0.003 & 0.428 & (0.788) & 0.348 & $<0.001$ \\
\hline PER1 & 0.190 & 0.478 & 0.473 & 0.239 & 0.378 & (0.859) & $<0.001$ \\
\hline PER2 & 0.027 & 0.297 & 0.282 & 0.003 & 0.039 & $(0.863)$ & $<0.001$ \\
\hline PER3 & 0.328 & 0.281 & 0.047 & 0.239 & 0.239 & $(0.870)$ & $<0.001$ \\
\hline PER4 & 0.199 & 0.418 & 0.238 & 0.118 & 0.473 & $(0.871)$ & $<0.001$ \\
\hline PER5 & 0.028 & 0.239 & 0.344 & 0.472 & 0.217 & $(0.932)$ & $<0.001$ \\
\hline PER6 & 0.172 & 0.328 & 0.349 & 0.029 & 0.119 & (0.869) & $<0.001$ \\
\hline PER7 & 0.418 & 0.021 & 0.032 & 0.182 & 0.092 & $(0.856)$ & $<0.001$ \\
\hline
\end{tabular}

Notes: Italic items are factor loadings; $\mathrm{ABI}=$ ability to transfer knowledge; $\mathrm{MOT}=$ motivation to transfer knowledge; OPP $=$ opportunity seeking to transfer knowledge; $\mathrm{KNO}=$ knowledge received by employees; $\mathrm{ABS}=$ employee absorptive capacity; PER = performance

their respective constructs. These test findings indicate good convergent validity. To assess discriminant validity, this study used multiple techniques. First, all latent variables correlations were lower than the square root of AVE of their respective constructs (Fornell and Larcker, 1981). Second, through chi-square difference test (Anderson and Gerbing, 1988), it was confirmed that correlations between each pair of constructs were significantly different from unity (i.e. 1.0). In addition, it can be observed that the correlation matrix in Table II, finding that the largest correlation was 0.59 less than recommended 0.71 (Mackenzie et al., 2011). Finally, as seen in Table III, all of the indicators loaded well onto their own latent factor and poorly on other factors. All of these test results suggest good discriminant validity.

To assess potential nonresponse bias, the author follows the method proposed by Armstrong and Overton (1977), the study tested whether there were significant differences among the early and late respondents. A total of 370 participants delivered the survey during the early stage, and 207 delivered the survey during the late stage. Moreover, the findings of the chi-square test did not demonstrate any significant differences between early and late respondents at the 5 per cent significance level. Accordingly, the probability of nonresponse bias was excluded.

Finally, to check for common method bias, a post-hoc test was applied using Harman's one-factor. In this, the first factor accounted for 30.37 per cent per cent of the variances which is less than the critical 50 per cent (the variances explained ranges from 19.32 per cent to 30.37 per cent). Hence, no major signs of common method bias were noted (Chin et al., 2012). In addition, following the method proposed by Liang et al. (2007), the results indicate that the substantive variance of indicators is 0.7 , the average method-based variance is 0.007 , and all the method factor loadings are not significant. 
Thus, it can be contended that common method bias may not be a serious problem in the data set.

\subsection{Structural model and hypotheses testing}

The research proceeds to the analysis of the results of the structural model. Here, the path coefficients $(\beta)$, the $p$ values and the $R^{2}$ values of the present framework are introduced in Figure 2. Findings indicate that the model explains 47 per cent of the variance in knowledge received by employee and 51 per cent of the variance in travel agents' performance. Based on the results, the strongest predictors of knowledge received by employee were manager

\section{Figure 2 (a) Path coefficient results of full sample; (b) results of high absorptive} capacity subgroup; (c) results of low absorptive capacity subgroup

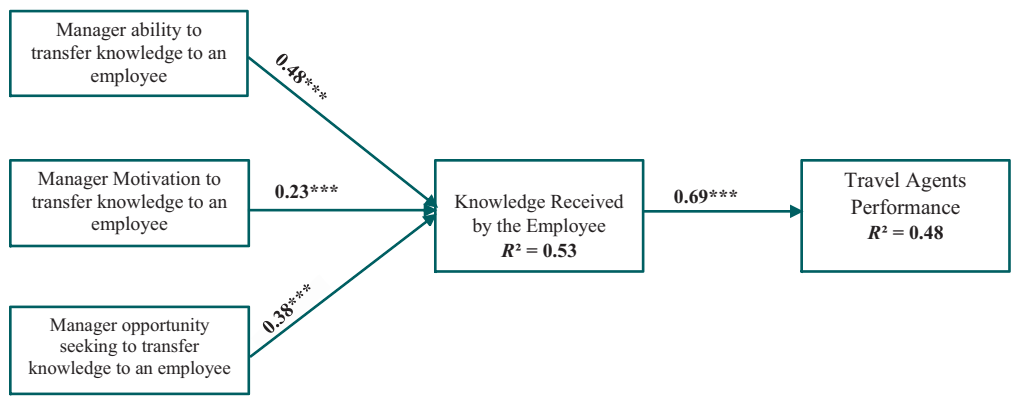

(a)

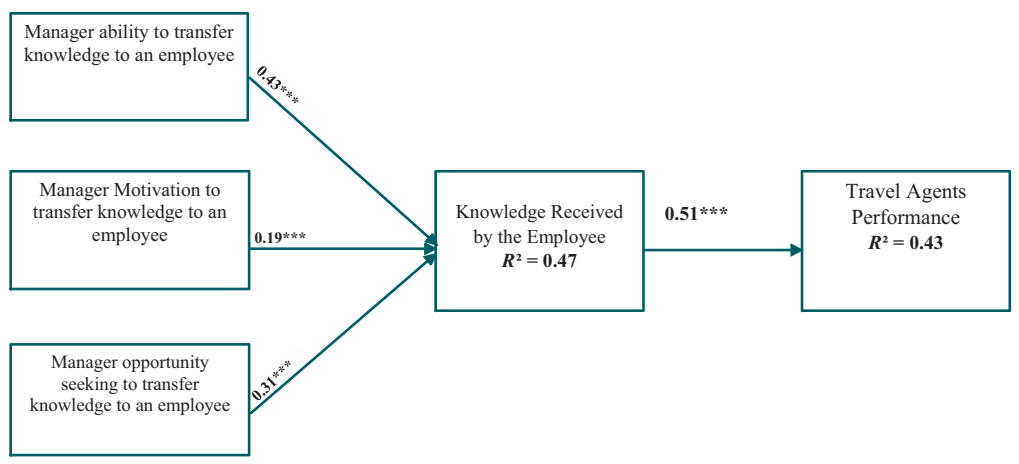

(b)

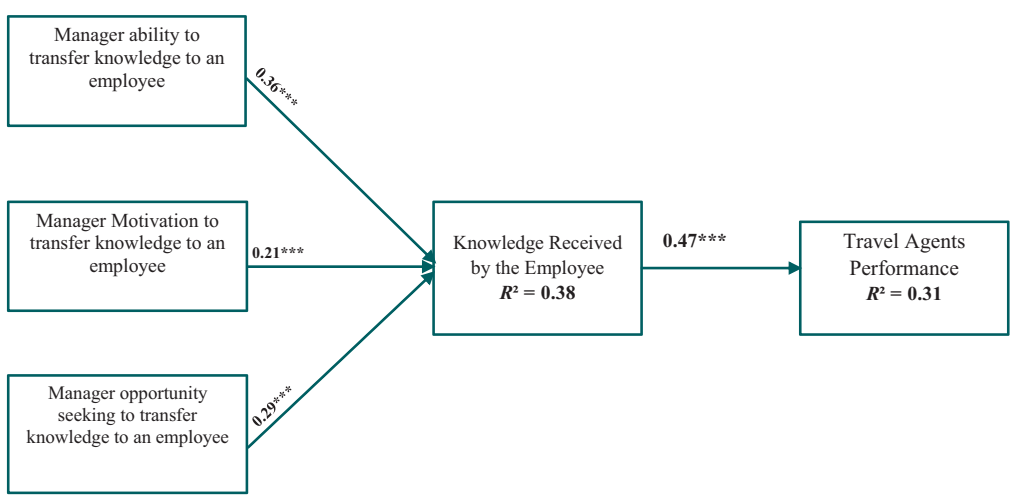

(c)

Notes: The asterisks represent the level of significance of the coefficient. $* 0.05$; $* * 0.01$; and $* * * 0.001$ 
ability to transfer knowledge ( $\beta=0.48, p<0.001)$, manager opportunity seeking to transfer knowledge $(\beta=0.38, p<0.001)$ and manager motivation to transfer knowledge $(\beta=0.23$, $p<0.001$ ). Therefore, the results support the suggested $H 1, H 2$ and $H 3$. Moreover, results show that knowledge received by employee is a significant and strong predictor of travel agents' performance $(\beta=0.69, p<0.001)$. Thus, the results support the suggested $H 4$.

Moreover, effect sizes $\left(f^{2}\right)$ were used to evaluate the extent to which the predictor latent variables affect the dependent variable. The following formula is adopted to estimate the effect size for each path coefficient:

$$
f^{2}=\left(R_{\text {included }}^{2}-R_{\text {excluded }}^{2}\right) /\left(1-R_{\text {included }}^{2}\right)
$$

As suggested by Chun et al. (2010), 0.02, 0.15 and 0.35 as operational definitions of small, medium and large effect sizes, respectively. Therefore, the study model suggested that knowledge received $\left(f^{2}=0.39\right)$ and travel agents' performance $\left(f^{2}=0.47\right)$ have large effect sizes.

A mediation analysis was applied to uncover the mediating role of knowledge received by employee in the link between manager competencies to transfer knowledge and travel agents performance (Table IV). A separate analysis was performed based on Baron and Kenny's (1986) procedure. The result has revealed that knowledge received by employee fully mediates the link between motivation to transfer knowledge, opportunity to transfer knowledge and travel agents' performance and partially mediates the relationships between ability to transfer knowledge and travel agents' performance. In other words, the positive influence of manager competencies to transfer knowledge (ability, motivation and opportunity seeking) on travel agents' performance is subject to the knowledge transferred by the travel agent employees.

To further test the moderating role of absorptive, we used the formula suggested by Chin et al. (2003) to assess the differences in path coefficients between the high-absorptive capacity subgroup model and the low-absorptive capacity subgroup model, $t$-statistics has been calculated, following Agag and El-Masry (2016) and Chang et al. (2012). As shown in Table $V$, manager ability to transfer knowledge, manager motivation and manager opportunity seeking to transfer knowledge have higher influence on knowledge received by the employee for employee with high levels of absorptive capacity. Therefore, H8, H9 and

Table IV Indirect effects/results

\begin{tabular}{|c|c|c|c|}
\hline Paths & Direct effect & $\begin{array}{l}\text { ficance } \\
\qquad \text { Indirect effect } \\
\text { via knowledge received }\end{array}$ & Outcome \\
\hline Motivation on performance & $p=0.23$ & $p=0.03$ & Full mediation at $5 \%$ \\
\hline Ability on performance & $p=0.01$ & $p=0.002$ & Partial mediation at $5 \%$ \\
\hline Opportunity seeking on performance & $p=0.18$ & $p=0.04$ & Full mediation at $5 \%$ \\
\hline
\end{tabular}

Table V Statistical comparison of paths

\begin{tabular}{|c|c|c|c|c|}
\hline Path & $\begin{array}{r}\text { Hig } \\
\text { capac } \\
\text { Standardized } \\
\text { path coefficient }\end{array}$ & $\mathrm{p}$-value & $\begin{array}{r}\text { Lov } \\
\text { capac } \\
\text { Standardized } \\
\text { path coefficient }\end{array}$ & t-value \\
\hline $\mathrm{ABI} \rightarrow \mathrm{KNO}$ & 0.43 & $<0.001$ & 0.36 & $<0.001$ \\
\hline $\mathrm{MOT} \rightarrow \mathrm{KNO}$ & 0.19 & $<0.001$ & 0.21 & $<0.01$ \\
\hline $\mathrm{OPP} \rightarrow \mathrm{KNO}$ & 0.31 & $<0.001$ & 0.29 & $<0.001$ \\
\hline $\mathrm{KNO} \rightarrow \mathrm{PER}$ & 0.51 & $<0.001$ & 0.47 & $<0.001$ \\
\hline
\end{tabular}

Notes: $\mathrm{ABI}=$ ability to transfer knowledge; $\mathrm{MOT}=$ motivation to transfer knowledge; OPP = opportunity seeking to transfer knowledge; $\mathrm{KNO}=$ knowledge received by employee 
H10 are supported. Finally, knowledge received by the employee exerts stronger influence on travel agents' performance for employee with high levels of absorptive capacity, indicating $\mathrm{H} 11$ is supported.

\section{Discussion, implications and limitations}

The main purpose of this study was to examine thoroughly the complex relationships between manager competencies: ability, motivation and opportunity to transfer knowledge and organizational performance in the context of travel agent. The major concerns are to investigate how employee's absorptive capacity moderates the effects of managers' competencies on knowledge received by the employees and moderates the effects of knowledge received by the employees on travel agents' performance. Moreover, the author examines the impact of managers' competencies in knowledge transfer on travel agents' performance through the knowledge received by the employees.

In addition, the study results identified the three antecedents of knowledge received by employee as manager ability, motivation and opportunity seeking to transfer knowledge have a positive effect on knowledge received by employee. All of the manager competencies are significant predictors of knowledge received by employees. These results are consistent with Wang and Noe (2010), who claimed that if the ability, motivation and opportunity to transfer knowledge of carriers are strong, the receivers will get more advance knowledge from the carriers, which leads to the result that employees can transform the knowledge into productive forces and improve the performance of organization. Moreover, Kelloway and Barling (2000) realized the role of ability, motivation and opportunities as an important competency for explaining the creation and transfer of knowledge.

The result revealed that knowledge received by employee fully mediates the link between motivation and opportunity to transfer knowledge and travel agents' performance and partially mediates the relationships between ability to transfer knowledge and travel agents' performance. These results are in line with Schreiber et al. (2011), who contended that the crucial element in knowledge transfer process is not the carrier of the original knowledge, but the receiver's perception of the effectiveness and applicability of this transmitted knowledge in its operations. Further data analysis based on Peng (2011) and Chang et al. (2012) indicated that the ability, motivation and opportunity of manager competencies will maximize the knowledge received by the employees, which in turn will enhance organizational performance.

The findings of the interaction model support the well-investigated framework of Chang et al. (2012) in which manager ability and opportunity seeking to transfer knowledge on knowledge received by employee is positively moderated by employee absorptive capacity Moreover, the results indicate that employee absorptive capacity moderates the effect on the link between manager motivation to transfer knowledge and knowledge received by an employee. It can be concluded that strong absorptive capacity of employees leads to the engagement of the recipient of knowledge and, thus, higher influence in knowledge transfer. Finally, the influence of knowledge received by an employee on travel agents' performance is positively moderated by the employee's absorptive capacity. These results are in line with Tsai (2001); Escribano et al. (2009) and Chang et al. (2012), who found that absorptive capacity positively moderates the relationship between external knowledge flows and innovation performance.

Based on the results of this research, the author would like to share several points worthy of consideration for theory development. First, the findings of this study contribute to the literature by expanding the extant literature on knowledge transfer and absorptive capacity by investigating the influence of travel agents' manager competencies - ability, motivation and opportunity seeking - for knowledge transfer in the Egyptian context. Second, the

VOL. 22 NO. 12018 JOURNAL OF KNOWLEDGE MANAGEMENT | PAGE 133 
present study established causality for the relationships between the study variables, using SEM. Third, despite the theoretical aspect attributed to ability, motivation and opportunity framework and absorptive capacity, comparatively little research focuses on its role within manager-employee relationships in travel agents in developing country. Thus, the successful development of the employees' ability to receive knowledge and their capacity to absorb it will contribute to a firm's achievement of competitive advantage. Fourth, the study results identified the three antecedents of knowledge received by employee as manager ability, motivation and opportunity seeking to transfer knowledge that has a positive effect on knowledge received by employee. Finally, the study findings show that the influence of knowledge received by employee on travel agents' performance is positively moderated by employee absorptive capacity. Hence, it can be concluded that strong absorptive capacity is vital and in turn leads to the involvement of the employees on knowledge transfer process and, thus, higher contribution in knowledge transfer. This argument supports Tsai's (2001) belief that absorptive capacity is possible to moderate the influence of network position on organization performance. Thus, the outcome of knowledge transfer on travel agents' performance depends on the extent to which employees can absorb such new knowledge.

Many studies have shown that if there is a strong desire to transfer knowledge between the holder and the receiver, this will be conclusive factor to the success of the transfer process and thus improve the performance of the organization (Kelloway and Barling, 2000; Argote et al., 2003; Wang and Noe, 2010; Chang et al., 2012; Abdul-Jalal et al., 2013). The study findings further indicate that the three antecedents of knowledge received by an employee as manager ability, motivation and opportunity seeking to transfer knowledge have a positive effect on knowledge received by employee. Therefore, achieving successful travel agents' performance and successful KM are based on ability, motivation and opportunity seeking of knowledge carrier and receiver. Thus, it is vital for successful knowledge transferring and building willingness of a group or an individual to work with others and share knowledge to their mutual benefit. This indicates that managers, employees and work groups in the Egyptian travel agents' context should have a high level of co-operation to ensure transferring knowledge successfully. It can be concluded that managers in the Egyptian travel agents who have the ability, motivation and opportunity to increase the level of knowledge sharing succeed by ensuring that the design of human resources management practices are customized to support the maximize of employees' knowledge sharing capabilities.

It is important for travel agents, owners, managers and employees to acknowledged absorptive capacity as a critical component for organization to sustain, grow and compete. Travel agents can also take steps to develop their employees' absorptive capacity. Doing so would further enhance the success of knowledge, employees and travel agents' performance. Also, travel agents' top management has to ensure their employees' absorbing knowledge, identifying and recognizing external knowledge, processing and understanding it, combining it with existing knowledge and applying the new knowledge to commercial ends. Hence, it can be observed that the successful development of absorptive capacity will contribute to a travel agent achievement of competitive advantage. Thus, travel agents are advised to ensure and provide a clear vision as to what their employees are trying to achieve with the knowledge received from their managers. Travel agents may train their employees on functional skills, multiple languages, developing trust and cooperation in knowledge transfer.

This study is bound by certain limitations that also provide fertile grounds for further research. First, the study examined how employee's absorptive capacity moderates the effects of managers' competencies on knowledge received by the employees and moderates the effects of knowledge received by the employees on travel agents' performance. However, innovation as a dependent variable can be investigated. Second, 
one limitation is that the study is restricted to Category A travel agents only in Greater Cairo. Third, examining the antecedents of ability, motivation and opportunity seeking to transfer knowledge is also important. Finally, any comparative study from a developed and developing country would make a worthwhile contribution to the body of knowledge.

\section{References}

Abdul-Jalal, H., Toulson, P. and Tweed, D. (2013), "Knowledge sharing success for sustaining organizational competitive advantage", Procedia Economics and Finance, Vol. 7 No. 2013, pp. 150-157.

Abou-Shouk, M.A., Lim, W.M. and Megicks, P. (2016), "Using competing models to evaluate the role of environmental pressures in ecommerce adoption by small and medium sized travel agents in a developing country", Tourism Management, Vol. 52 No. 2016, pp. 327-339.

Adler, J.H. (1965), Absorptive Capacity: The Concept and its Determinants, Brookings Institution, Washington, DC.

Agag, G.M. and El-Masry, A.A. (2016), "Understanding the determinants of hotel booking intentions and moderating role of habit", International Journal of Hospitality Manaqement, Vol. 54, pp. 52-67.

Agag, G.M. and El-Masry, A.A. (2017), "Why do consumers trust online travel websites? Drivers and outcomes of consumer trust toward online travel websites", Journal of Travel Research, Vol. 56 No. 3, pp. 347-369.

Ajmal, M.M. and Koskinen, K.U. (2008), "Knowledge transfer in project-based organizations: an organizational culture perspective", Project Management Journal, Vol. 39 No. 1, pp. 7-15.

Anantatmula, V.S. and Stankosky, M. (2008), "KM criteria for different types of organizations", International Journal of Knowledge and Learning, Vol. 4 No. 1, pp. 18-35.

Anderson, J.C. and Gerbing, D.W. (1988), "Structural equation modeling in practice: a review and recommended two-step approach", Psychological Bulletin, Vol. 103 No. 3, p. 411.

Argote, L. and Ingram, P. (2000), "Knowledge transfer: a basis for competitive advantage in firms", Organizational Behavior and Human Decision Processes, Vol. 82 No. 1, pp. 150-169.

Argote, L., McEvily, B. and Reagans, R. (2003), "Managing knowledge in organizations: an integrative framework and review of emerging themes", Management Science, Vol. 49 No. 4, pp. 571-582.

Armstrong, J.S. and Overton, T.S. (1977), "Estimating nonresponse bias in mail surveys", Journal of Marketing Research, Vol. 14 No. 3, pp. 396-402.

Bagozzi, R.P. and Yi, Y. (1988), "On the evaluation of structural equation models", Journal of the Academy of Marketing Science, Vol. 16 No. 1, pp. 74-94

Baloglu, S. and Mangaloglu, M. (2001), "Tourism destination images of Turkey, Egypt, Greece, and Italy as perceived by US-based tour operators and travel agents", Tourism Management, Vol. 22 No. 1, pp. 1-9.

Baron, R.M. and Kenny, D.A. (1986), "The moderator-mediator variable distinction in social psychological research: conceptual, strategic, and statistical considerations", Journal of Personality and Social Psychology, Vol. 51 No. 6, pp. 1173-1182.

Bartlett, J.E., Kotrlik, J.W. and Higgins, C.C. (2001), "Organizational research: determining appropriate sample size in survey research", Information Technology, Learning, and Performance Journal, Vol. 19 No. 1, pp. 43-50.

Bosua, R. and Venkitachalam, K. (2013), "Aligning strategies and processes in knowledge management: a framework", Journal of Knowledge Management, Vol. 17 No. 3, pp. 331-346.

Carmines, E. and Zeller, R. (1979), Reliability and Validity Assessment, Sage Publication, Newbury Park, CA.

Chang, Y.Y., Gong, Y. and Peng, M.W. (2012), "Expatriate knowledge transfer, subsidiary absorptive capacity, and subsidiary performance", Academy of Management Journal, Vol. 55 No. 4, pp. 927-948.

Chin, W.W., Marcolin, B.L. and Newsted, P.R. (2003), "A partial least squares latent variable modeling approach for measuring interaction effects: results from a Monte Carlo simulation study and an electronic-mail emotion/adoption study", Information Svstems Research, Vol. 14 No. 2, pp. 189-217. 
Chin, W.W., Thatcher, J.B. and Wright, R.T. (2012), "Assessing common method bias: problems with the ULMC technique", MIS Quarterly, Vol. 36 No. 3, pp. 1003-1019.

Chun, J.U., Litzky, B.E., Sosik, J.J., Bechtold, D.C. and Godshalk, V.M. (2010), "Emotional intelligence and trust in formal mentoring programs", Group \& Organization Management, Vol. 35 No. 4, pp. 421-455.

Cohen, W. and Levinthal, D. (1990), "Absorptive capacity: a new perspective on learning and innovation", Administrative Science Quarterly, Vol. 35 No. 1, pp. 128-152.

Colquitt, J.A. and Simmering, M.J. (1998), "Conscientiousness, goal orientation, and motivation to learn during the learning process: a longitudinal study", Journal of Applied Psychology, Vol. 83 No. 4, pp. 654-665.

Conger, J.A., Kanungo, R.N. and Menon, S.T. (2000), "Charismatic leadership and follower effects", Journal of Organizational Behavior, Vol. 21 No. 7, pp. 747-767.

Darr, E.D., Argote, L. and Epple, D. (1995), "The acquisition, transfer, and depreciation of knowledge in service organizations: productivity in franchises", Management Science, Vol. 41 No. 11, pp. $1750-1762$.

Davenport, T.H. and Prusak, L. (1998), Working Knowledge: How Organizations Manage What they Know, Harvard Business Press, Boston, MA.

Dobre, O. (2013), "Employee motivation and organizational performance", Review of Applied SocioEconomic Research, Vol. 5 No. 1, pp. 53-60.

Easterby-Smith, M., Lyles, M.A. and Tsang, E.W. (2008), "Inter-organizational knowledge transfer: current themes and future prospects", Journal of Management Studies, Vol. 45 No. 4, pp. 677-690.

Egyptian Ministry of Tourism (2015), Egyptian Tourism Statistics, Egyptian Ministry of Tourism, available at: www.tourism.gov.eg/Pages/TourismIndicators.aspx (accessed 3 January 2017).

Elbaz, A.M. and Abou-Shouk, M.A. (2016), "The role of tourism-related organization networks in developing sustainable community livelihoods", Journal of Basic and Environmental Sciences, Vol. 3, pp. 112-122.

Elbaz, A.M. and Haddoud, M.Y. (2017), "The role of wisdom leadership in increasing job performance: evidence from the Egyptian tourism sector”, Tourism Management, Vol. 63, pp. 66-76.

Escribano, A., Fosfuri, A. and Tribó, J.A. (2009), "Managing external knowledge flows: the moderating role of absorptive capacity", Research Policy, Vol. 38 No. 1, pp. 96-105.

Ettlie, J.E. and Pavlou, P.A. (2006), "Technology-based new product development partnerships", Decision Sciences, Vol. 37 No. 2, pp. 117-147.

Fei, J., Chen, S. and Chen, S.L. (2009), "Organizational knowledge base and knowledge transfer in the shipping industry", Electronic Journal of Knowledge Management, Vol. 7 No. 3, pp. 325-340.

Fornell, C. and Larcker, D.F. (1981), "Structural equation models with unobservable variables and measurement error: algebra and statistics", Journal of Marketing Research, Vol. 18 No. 3, pp. 382-388.

Frechtling, D.C. (2004), "Assessment of tourism/hospitality journals' role in knowledge transfer: an exploration study", Journal of Travel Research, Vol. 43, pp. 100-107.

Gold, A.H., Malhotra, A. and Segars, A.H. (2001), "Knowledge management: an organizational capabilities perspective", Journal of Management Information Systems, Vol. 18 No. 1, pp. 185-214.

Hair, J.F. Jr, Hult, G.T.M., Ringle, C. and Sarstedt, M. (2016), A Primer on Partial Least Squares Structural Equation Modeling (PLS-SEM), Sage Publications, Thousand Oaks, CA.

Henseler, J., Ringle, C.M. and Sinkovics, R.R. (2009), "The use of partial least squares path modeling in international marketing", Advances in International Marketing, Vol. 20 No. 1, pp. 277-319.

Henseler, J., Hubona, G. and Ray, P.A. (2016), "Using PLS path modeling in new technology research: updated guidelines", Industrial Management \& Data Systems, Vol. 116 No. 1, pp. 2-20.

Hilmi, N., Safa, A., Reynaud, S. and Allemand, D. (2012), "Coral reefs and tourism in Egypt's Red Sea", Topics in Middle Eastern \& African Economies, Vol. 14, pp. 416-443.

Hislop, D. (2013), Knowledge Management in Organizations: A Critical Introduction, Oxford University Press, Oxford. 
Hussain, F., Lucas, C. and Ali, M. (2004), "Managing knowledge effectively", Journal of Knowledge Management Practice, Vol. 5 No. 1, pp. 1-12.

Ismail, M. (2015), "Conceptualizing knowledge transfer between expatriates and host country nationals: the mediating effect of social capital", Cogent Business \& Management, Vol. 2 No. 1, pp. 1-16.

Jeon, S., Kim, Y.G. and Koh, J. (2011), "An integrative model for knowledge sharing in communities-of-practice", Journal of Knowledge Management, Vol. 15 No. 2, pp. 251-269.

Jimenéz-Jimenéz, D., Martínez-Costa, M. and Sanz-Valle, R. (2014), "Innovation, organizational learning orientation and reverse knowledge transfer in multinational companies", Electronic Journal of Knowledge Management, Vol. 12 No. 1, pp. 47-55.

Johnson, H. (2007), "Communities of practice and international development", Progress in Development Studies, Vol. 7 No. 4, pp. 277-290.

Junni, P., Sarala, K.M. and Vaara, E. (2012), "The dynamics of knowledge transfer in mergers and acquisitions", in Faulkner, D., Teerikangas, S. and Joseph, R. (Eds), Handbook of Research on Mergers and Acquisitions, Oxford University Press, Oxford.

Kamal, E.M. and Flanagan, R. (2014), "Model of absorptive capacity and implementation of new technology for rural construction SMEs", Australasian Journal of Construction Economics and Building Conference Series, Vol. 2 No. 2, pp. 19-26.

Kamhawi, E. (2012), "Knowledge management fishbone: a standard framework of organizational enablers", Journal of Knowledge Management, Vol. 16 No. 5, pp. 808-828.

Kelloway, E.K. and Barling, J. (2000), "Knowledge work as organizational behavior", International Journal of Management Reviews, Vol. 2 No. 3, pp. 287-304.

Kock, N. and Lynn, G. (2012), "Lateral collinearity and misleading results in variance-based SEM: an illustration and recommendations", Journal of the Association for Information Systems, Vol. 13 No. 7 , pp. 1-40.

Kocoglu, I., Akgün, A.E. and Keskin, H. (2015), "The differential relationship between absorptive capacity and product innovativeness: a theoretically derived framework", International Business Research, Vol. 8 No. 7, pp. 108-120.

Lawson, B. and Potter, A. (2012), "Determinants of knowledge transfer in inter-firm new product development projects", International Journal of Operations \& Production Management, Vol. 32 No. 10, pp. $1228-1247$.

Lesser, E. and Storck, J. (2001), "Communities of practice and organizational performance", IBM Systems Journal, Vol. 40 No. 4, pp. 831-841.

Liang, H., Saraf, N., Hu, Q. and Xue, Y. (2007), "Assimilation of enterprise systems: the effect of institutional pressures and the mediating role of top management”, MIS Quarterly, Vol. 31 No. 1, pp. 59-87.

Lin, T.C., Chang, C.L.H. and Tsai, W.C. (2016), "The influences of knowledge loss and knowledge retention mechanisms on the absorptive capacity and performance of a MIS department", Management Decision, Vol. 54 No. 7, pp. 1757-1787.

Lowry, P.B. and Gaskin, J. (2014), "Partial least squares (PLS) structural equation modeling (SEM) for building and testing behavioral causal theory: when to choose it and how to use it", IEEE Transactions on Professional Communication, Vol. 57 No. 2, pp. 123-146.

MacKenzie, S.B., Podsakoff, P.M. and Podsakoff, N.P. (2011), "Construct measurement and validation procedures in MIS and behavioral research: integrating new and existing techniques", MIS Quarterly, Vol. 35 No. 2, pp. 293-334.

McCall, H., Arnold, V. and Sutton, S.G. (2008), "Use of knowledge management systems and the impact on the acquisition of explicit knowledge", Journal of Information Svstems, Vol. 22 No. 2, pp. 77-101.

McGehee, N.G., Lee, S., O'Bonnon, T.L. and Perdue, R.R. (2010), "Tourism-related social capital and its relationship with other forms of social capital: an exploratory study", Journal of Travel Research, Vol. 49, pp. 486-500.

Martin, X. and Salomon, R. (2003), "Knowledge transfer capacity and its implications for the theory of the multinational corporation", Journal of International Business Studies, Vol. 34 No. 4, pp. 356-373. 
Massa, S. and Testa, S. (2009), "A knowledge management approach to organizational competitive advantage: evidence from the food sector", European Management Journal, Vol. 27 No. 2, pp. 129-141.

Meihami, B. and Meihami, H. (2014), "Knowledge management a way to gain a competitive advantage in firms (evidence of manufacturing companies)", International Letters of Social and Humanistic Sciences, Vol. 14, pp. 80-91.

Minbaeva, D., Pedersen, T., Björkman, I., Fey, C.F. and Park, H.J. (2003), "MNC knowledge transfer, subsidiary absorptive capacity, and HRM", Journal of International Business Studies, Vol. 34 No. 6, pp. 586-599.

Mowery, D.C., Oxley, J.E. and Silverman, B.S. (1996), "Strategic alliances and interfirm knowledge transfer”, Strategic Management Journal, Vol. 17 No. S2, pp. 77-91.

Murray, S. and Peyrefitte, J. (2007), "Knowledge type and communication media choice in the knowledge transfer process", Journal of Managerial Issues, Vol. 19 No. 1, pp. 111-133.

Nahapiet, J. and Ghoshal, S. (1998), "Social capital, intellectual capital, and the organizational advantage", Academv of Management Review, Vol. 23 No. 2, pp. 242-266.

Nonaka, I. (1994), "A dynamic theory of organizational knowledge creation", Orqanization Science, Vol. 5 No. 1, pp. 14-37.

Nunnally, J.C. and Bernstein, I.H. (1994), Psychological Theory, MacGraw-Hill, New York, NY.

Omotayo, F. (2015), "Knowledge management as an important tool in organizational management: a review of literature", Library Philosophy and Practice (e-journal), Vol. 1238, pp. 1-23, available at: http://digitalcommons.unl.edu/cgi/viewcontent.cgi?article=3330\&context=libphilprac

Paulin, D. and Suneson, K. (2012), "Knowledge transfer, knowledge sharing and knowledge barriers-three blurry terms in KM", Electronic Journal of Knowledge Management, Vol. 10 No. 1, pp. 81-91.

Peng, M.W. (2011), Global Business (2nd ed.), South-Western Cengage Learning, Cincinnati, OH.

Polanyi, M. (1966), The Tacit Dimension, Doubleday and Company Inc, New York, NY.

Potnuru, R.K.G. and Sahoo, C.K. (2016), "HRD interventions, employee competencies and organizational effectiveness: an empirical study", European Journal of Training and Development, Vol. 40 No. 5, pp. 345-365.

Richter, T. and Steiner, C. (2008), "Politics, economics \& tourism development in Egypt: insights into the sectoral transformations of a neo-patrimonial rentier state", Third World Quarterly, Vol. 29 No. 5, pp. 939-959.

Roberts, J. (2000), "From know-how to show-how? Questioning the role of information and communication technologies in knowledge transfer", Technology Analysis \& Strategic Management, Vol. 12 No. 4, pp. 429-443.

Sanchez-Vidal, M.E., Sanz-Valle, R. and Barba-Aragon, M.I. (2016), "Repatriates and reverse knowledge transfer in MNCs", The International Journal of Human Resource Management, pp. 1-19, available at: https://doi.org/10.1080/09585192.2016.1216876

Schreiber, D., Junior, V., Chaves, D., Vargas, L.M. and Maçada, A.C.G. (2011), "Knowledge transfer in product development: an analysis of Brazilian subsidiaries of multinational corporations", BAR-Brazilian Administration Review, Vol. 8 No. 3, pp. 288-304.

Seidler-de Alwis, R. and Hartmann, E. (2008), "The use of tacit knowledge within innovative companies: knowledge management in innovative enterprises", Journal of knowledge Management, Vol. 12 No. 1, pp. 133-147.

Siemsen, E., Roth, A.V. and Balasubramanian, S. (2008), "How motivation, opportunity, and ability drive knowledge sharing: the constraining-factor model", Journal of Operations Management, Vol. 26 No. 3, pp. 426-445.

Smith, E.A. (2001), "The role of tacit and explicit knowledge in the workplace", Journal of Knowledge Management, Vol. 5 No. 4, pp. 311-321.

Steiner, C. (2006), "Tourism, poverty reduction and the political economy: Egyptian perspectives on tourism's economic benefits in a semi-rentier state", Tourism and Hospitality Planning \& Development, Vol. 3 No. 3, pp. 161-177. 
Syed-Ikhsan, S.O.S. and Rowland, F. (2004), "Knowledge management in a public organization: a study on the relationship between organizational elements and the performance of knowledge transfer", Journal of Knowledae Management, Vol. 8 No. 2, pp. 95-111.

Szulanski, G. (1996), "Exploring internal stickiness: impediments to the transfer of best practice within the firm", Strategic Management Journal, Vol. 17 No. S2, pp. 27-43.

Tho, N.D. and Trang, N.T.M. (2015), "Can knowledge be transferred from business schools to business organizations through in-service training students? SEM and fsQCA findings", Journal of BusinesS Research, Vol. 68 No. 6, pp. 1332-1340.

Tsai, W. (2001), "Knowledge transfer in intraorganizational networks: effects of network position and absorptive capacity on business unit innovation and performance", Academy of Management Journal, Vol. 44 No. 5, pp. 996-1004.

Turner, T. and Pennington, W.W. III (2015), "Organizational networks and the process of corporate entrepreneurship: how the motivation, opportunity, and ability to act affect firm knowledge, learning, and innovation", Small Business Economics, Vol. 45 No. 2, pp. 447-463.

Volberda, H., Foss, N. and Lyles, M. (2009), "Absorbing the concept of absorptive capacity: how to realize its potential in the organization field", Organization Science, Vol. 21 No. 4, pp. 931-951.

Wang, S. and Noe, R.A. (2010), "Knowledge sharing: a review and directions for future research", Human Resource Management Review, Vol. 20 No. 2, pp. 115-131.

Wang, Z. and Wang, N. (2012), "Knowledge sharing, innovation and firm performance", Expert Systems with Applications, Vol. 39 No. 10, pp. 8899-8908.

Wei, X. and Xie, F. (2008), "Knowledge management processes and innovation: an empirical analysis of firms in software cluster", International Journal of Human Resources Development and Management, Vol. 8 Nos 1/2, pp. 25-42.

Westland, C.J. (2010), "Lower bounds on sample size in structural equation modeling", Electronic Commerce Research and Applications, Vol. 9 No. 6, pp. 476-487.

Wood, G., Dibben, P. and Meira, J. (2016), "Knowledge transfer within strategic partnerships: the case of HRM in the Brazilian motor industry supply chain", The International Journal of Human Resource Management, Vol. 27 No. 20, pp. 2398-2414.

Yahiaoui, D., Chebbi, H. and Weber, Y. (2016), "HR practices, context and knowledge transfer in M\&A", The International Journal of Human Resource Management, Vol. 27 No. 20, pp. 2415-2435.

Yusof, M.N. and Bakar, A.H.A. (2012), "Knowledge management and growth performance in construction companies: a framework", Procedia-Social and Behavioral Sciences, Vol. 62, pp. 128-134.

Zack, M.H. (1999), "Managing codified knowledge", MIT Sloan Management Review, Vol. 40 No. 4, pp. $45-58$

Zahra, S.A. and George, G. (2002), "Absorptive capacity: a review, reconceptualization, and extension", Academv of Management Review, Vol. 27 No. 2, pp. 185-203.

\section{Further reading}

Chan, F.K. and Thong, J.Y. (2009), "Acceptance of agile methodologies: a critical review and conceptual framework", Decision Support Systems, Vol. 46 No. 4, pp. 803-814.

Kock, N. (2015), WarpPLS 5.0 User Manual, ScriptWarp Systems, Laredo, TX.

Leonidou, L.C., Kvasova, O., Leonidou, C.N. and Chari, S. (2013), "Business unethicality as an impediment to consumer trust: the moderating role of demographic and cultural characteristics", Journal of Business Ethics, Vol. 112 No. 3, pp. 397-415.

Sharma, D., Borna, S. and Stearns, J.M. (2009), "An investigation of the effects of corporate ethical values on employee commitment and performance: examining the moderating role of perceived fairness", Journal of Business Ethics, Vol. 89 No. 2, pp. 251-260.

Zhao, Z.J. and Anand, J. (2009), "A multilevel perspective on knowledge transfer: evidence from the Chinese automotive industry", Strategic Management Journal, Vol. 30 No. 9, pp. 959-983. 


\section{Appendix}

Table Al Descriptive statistics and normality tests of the constructs in the model

\begin{tabular}{|c|c|c|c|c|c|c|}
\hline Statistics & Mean & $S D$ & $\begin{array}{l}\text { Corrected } \\
\text { correlation } \\
\text { item-total }\end{array}$ & Skewness & Kurtosis & $\begin{array}{l}\text { Supporting } \\
\text { literature }\end{array}$ \\
\hline \multicolumn{7}{|l|}{ Ability to transfer knowledge (ABI) } \\
\hline $\begin{array}{l}\text { I have a lot of good ideas worth } \\
\text { sharing (ABI1) }\end{array}$ & 3.9 & 0.874 & 0.682 & -0.586 & 0.714 & \multirow{4}{*}{$\begin{array}{l}\text { Siemsen et al. } \\
\text { (2008); } \\
\text { Chang et al. } \\
\text { (2012); } \\
\text { Turner and } \\
\text { Pennington } \\
\text { (2015) }\end{array}$} \\
\hline $\begin{array}{l}\text { I am capable of sharing important } \\
\text { information (ABI2) }\end{array}$ & 4.2 & 0.786 & 0.693 & -0.694 & 0.093 & \\
\hline $\begin{array}{l}\text { I have the ability to communicate } \\
\text { good ideas about my Business } \\
\text { (ABI3) }\end{array}$ & 4.6 & 0.789 & 0.729 & -0.701 & 0.580 & \\
\hline $\begin{array}{l}\text { I possess superior managerial } \\
\text { (people) competencies } \\
\text { (Knowledge, skills and experience) } \\
\text { to solve difficulties in the } \\
\text { knowledge transfer process (ABI4) }\end{array}$ & 4.8 & 0.735 & 0.602 & -0.684 & 0.781 & \\
\hline \multicolumn{7}{|l|}{$\begin{array}{l}\text { Motivation to transfer knowledge } \\
\text { (MOT) }\end{array}$} \\
\hline $\begin{array}{l}\text { I am not afraid of losing power and } \\
\text { control to solve difficulties to } \\
\text { transfer knowledge to my } \\
\text { subordinates (MOT1) }\end{array}$ & 4.2 & 0.792 & 0.652 & -0.489 & 0.732 & \multirow{5}{*}{$\begin{array}{l}\text { Siemsen et al. } \\
\text { (2008); } \\
\text { Chang et al. } \\
\text { (2012); } \\
\text { Turner and } \\
\text { Pennington } \\
\text { (2015) }\end{array}$} \\
\hline $\begin{array}{l}\text { I am willing to solve difficulties to } \\
\text { transfer knowledge to my } \\
\text { subordinates (MOT2) }\end{array}$ & 3.9 & 0.817 & 0.587 & -0.637 & 0.548 & \\
\hline $\begin{array}{l}\text { I am willing to cope with cultural } \\
\text { differences to transfer knowledge } \\
\text { to my subordinates (MOT3) }\end{array}$ & 4.7 & 0.893 & 0.628 & -0.738 & 0.493 & \\
\hline $\begin{array}{l}\text { I am willing to devote time to solve } \\
\text { difficulties to transfer knowledge to } \\
\text { my subordinates (MOT4) }\end{array}$ & 4.3 & 0.809 & 0.682 & -0.648 & 0.390 & \\
\hline $\begin{array}{l}\text { I am willing to make persistent } \\
\text { efforts to solve difficulties to } \\
\text { transfer knowledge to my } \\
\text { subordinates (MOT5) }\end{array}$ & 4.1 & 0.798 & 0.690 & -0.629 & 0.362 & \\
\hline \multicolumn{7}{|l|}{$\begin{array}{l}\text { Opportunity seeking to transfer } \\
\text { knowledge (OPP) }\end{array}$} \\
\hline $\begin{array}{l}\text { I seek opportunities through social } \\
\text { relationships to solve difficulties in } \\
\text { the knowledge transfer process } \\
\text { (OPP1) }\end{array}$ & 4.8 & 0.873 & 0.583 & -0.487 & 0.632 & \multirow{4}{*}{$\begin{array}{l}\text { Siemsen et al. } \\
\text { (2008); } \\
\text { Chang et al. } \\
\text { (2012); } \\
\text { Turner and } \\
\text { Pennington } \\
\text { (2015) }\end{array}$} \\
\hline $\begin{array}{l}\text { I utilize social ties to generate trust } \\
\text { and cooperation to solve difficulties } \\
\text { in the knowledge transfer process } \\
\text { (OPP2) }\end{array}$ & 4.2 & 0.890 & 0.673 & -0.589 & 0.367 & \\
\hline $\begin{array}{l}\text { I have the opportunity to share } \\
\text { information (OPP3) }\end{array}$ & 4.7 & 0.782 & 0.760 & -0.398 & 0.093 & \\
\hline $\begin{array}{l}\text { Sharing information is a priority in } \\
\text { our relationship (OPP4) }\end{array}$ & 4.6 & 0.816 & 0.691 & -0.682 & 0.189 & \\
\hline \multicolumn{7}{|l|}{ Knowledge received (KNO) } \\
\hline $\begin{array}{l}\text { Technological know-how and skills } \\
\text { (KNO1) }\end{array}$ & 4.6 & 0.873 & 0.730 & -0.549 & 0.543 & \multirow[t]{4}{*}{$\begin{array}{l}\text { Chang et al. } \\
(2012)\end{array}$} \\
\hline $\begin{array}{l}\text { Repair-related know-how and skills } \\
\text { (KNO2) }\end{array}$ & 4.3 & 0.798 & 0.648 & -0.742 & 0.218 & \\
\hline $\begin{array}{l}\text { Managerial know-how and skills } \\
\text { (KNO3) }\end{array}$ & 4.8 & 0.834 & 0.703 & -0.584 & 0.412 & \\
\hline $\begin{array}{l}\text { Knowledge about corporate culture } \\
\text { (KNO4) }\end{array}$ & 4.1 & 0.804 & 0.594 & -0.394 & 0.398 & \\
\hline
\end{tabular}

PAGE 140 | JOURNAL OF KNOWLEDGE MANAGEMENT | VOL. 22 NO. 12018 
Table Al

\begin{tabular}{|c|c|c|c|c|c|c|}
\hline Statistics & Mean & $S D$ & $\begin{array}{l}\text { Corrected } \\
\text { correlation } \\
\text { item-total }\end{array}$ & Skewness & Kurtosis & $\begin{array}{l}\text { Supporting } \\
\text { literature }\end{array}$ \\
\hline \multicolumn{7}{|l|}{ Absorptive capacity (ABS) } \\
\hline $\begin{array}{l}\text { Have the ability to acquire new } \\
\text { knowledge from managers to } \\
\text { achieve the travel agency targets } \\
\text { (ABS1) }\end{array}$ & 4.3 & 0.881 & 0.680 & -0.459 & 0.034 & $\begin{array}{l}\text { Ettlie and } \\
\text { Pavlou } \\
\text { (2006); }\end{array}$ \\
\hline $\begin{array}{l}\text { Have the technical competency to } \\
\text { absorb the knowledge from the } \\
\text { managers (ABS2) }\end{array}$ & 4.1 & 0.798 & 0.673 & -0.638 & 0.587 & $\begin{array}{l}\text { Lawson and } \\
\text { Potter (2012); }\end{array}$ \\
\hline $\begin{array}{l}\text { Have the ability to convert } \\
\text { knowledge or the practices from } \\
\text { the managers (ABS3) }\end{array}$ & 4.7 & 0.736 & 0.598 & -0.589 & 0.387 & $\begin{array}{l}\text { Chang et al. } \\
\text { (2012). }\end{array}$ \\
\hline $\begin{array}{l}\text { Have the ability to exploit new } \\
\text { knowledge or practices from the } \\
\text { managers (ABS4) }\end{array}$ & 4.4 & 0.903 & 0.703 & -0.741 & 0.587 & \\
\hline \multicolumn{7}{|l|}{ Travel agent performance (PER) } \\
\hline $\begin{array}{l}\text { Innovate new products/services } \\
\text { (PER1) }\end{array}$ & 4.6 & 0.880 & 0.648 & -0.548 & 0.041 & \multirow[t]{2}{*}{$\begin{array}{l}\text { Gold's et al. } \\
\text { (2001) }\end{array}$} \\
\hline $\begin{array}{l}\text { Identify new business opportunities } \\
\text { (PER2) }\end{array}$ & 4.2 & 0.873 & 0.740 & -0.293 & 0.548 & \\
\hline $\begin{array}{l}\text { Coordinate the development efforts } \\
\text { of different units (PER3) }\end{array}$ & 3.9 & 0.921 & 0.598 & -0.648 & 0.592 & \multirow[t]{5}{*}{$\begin{array}{l}\text { Potnuru and } \\
\text { Sahoo (2016) }\end{array}$} \\
\hline $\begin{array}{l}\text { Rapidly commercialize new } \\
\text { innovations (PER4) }\end{array}$ & 4.1 & 0.798 & 0.673 & -0.491 & 0.438 & \\
\hline $\begin{array}{l}\text { Adapt quickly to unanticipated } \\
\text { changes (PER5) }\end{array}$ & 4.7 & 0.751 & 0.759 & -0.185 & 0.218 & \\
\hline $\begin{array}{l}\text { Decrease market response times } \\
\text { (PER6) }\end{array}$ & 4.5 & 0.840 & 0.647 & -0.583 & 0.421 & \\
\hline $\begin{array}{l}\text { Avoid overlapping development of } \\
\text { corporate initiatives (PER7) }\end{array}$ & 4.8 & 0.772 & 0.590 & -0.752 & 0.389 & \\
\hline
\end{tabular}

\section{About the authors}

Ahmed Mohamed Elbaz holds a PhD of Tourism and Hospitality from the UK, Plymouth University. He is a Lecturer at the Faculty of Tourism and Hotels, University of Sadat City, Egypt. His research interests are tourism actor-networks, leadership in tourism, knowledge transfer, collaboration, environmental protection, sustainable livelihood, poverty reduction, sustainable tourism development, governance in developing countries and SEM, CB-SEM and PLS-SEM analysis in tourism. Ahmed Mohamed Elbaz is the corresponding author and can be contacted at: ahmed.elbaz@fth.usc.edu.eg

Gomaa Mohamed Agag joined Plymouth Business School in March 2012. Prior to this, he worked in many academic institutions including Menofia University, Egypt, Sadat City University, Egypt. Dr Agag's publications largely relate to electronic commerce, information systems in developing countries, social networking, international business, tourism management. Dr Agag has more than 15 journal and conference papers published or accepted for publication in Journal of Business Ethics, Journal of Travel Research, Journal of World Business and Journal of Internet Research. Dr Agag worked as a consultant for some industrial companies in Egypt.

Nasser Alhamar Alkathiri is a Lecturer at College of Applied Sciences, Salalah, Ministry of Higher Education, Sultanate of Oman Currently, he is the Acting Head of Business Administration Department, College of Applied Sciences, Salalah, Ministry of Higher Education, Sultanate of Oman. His research interests includes knowledge transfer, localization and entrepreneurship orientation.

For instructions on how to order reprints of this article, please visit our website:

www.emeraldgrouppublishing.com/licensing/reprints.htm

Or contact us for further details: permissions@emeraldinsight.com 